\title{
AKAP13 wt Allele
}

National Cancer Institute

\section{Source}

National Cancer Institute. AKAP13 wt Allele. NCI Thesaurus. Code C52455.

Human AKAP13 wild-type allele is located within 15q24-q25 and is approximately $515 \mathrm{~kb}$

in length. This allele, which encodes A-kinase anchor protein 13, is involved in both the regulation of the localization of protein kinase $A$ and the stimulation of guanidine nucleotide exchange factors. 